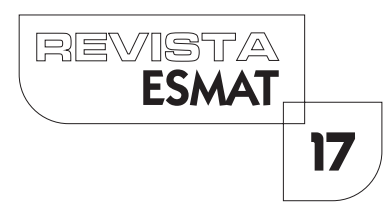

\title{
THE CONVENTION ON THE RIGHTS OF PERSONS WITH DISABILITIES: ITS CONTRIBUTION TO THE DEVELOPMENT OF INTERNATIONAL HUMAN RIGHTS LAW
}

Mona Paré

Associate Professor, University of Ottawa, Faculty of Law, Canada

\section{SUMMARY}

This article examines the impact that the United Nations Convention on the Rights of Persons with Disabilities (CRPD) has had on international human rights law. While it seems that the convention may have a narrow focus, as it focuses on a specific group of people, this paper argues that it has had an impact on international human rights law more generally. This impact started with the negotiation of the convention between 2002 and 2006, and is continuing with its implementation since its entry into force in 2008. The impact is of both procedural and substantive nature. On the one hand, the procedure that led to the development and adoption of the CRPD was innovative, as are the mechanisms that have been put into place to monitor its implementation. On the other hand, the convention introduces and develops concepts in a novel way in international law, such as new ways of considering the concept of equality, and to understand development, for example. The article concludes that the international community should capitalize on the new approaches, and that their application and interpretation should be closely monitored.

KEY WORDS: Persons with disabilities, international law, human rights, equality, development

\section{INTRODUCTION}

"Nothing About us Without Us". The motto of the disabled people's community was applied in a very concrete way with the development of the United Nations (UN) Convention on the Rights of Persons with Disabilities (CRPD) between 2002 and 2006, followed by its adoption on 13 December 2006. It was nothing short of a victory for persons with disabilities who, according to the United Nations (2007, p. I), represent the world's largest minority. According to different estimates, between 10 and 15\% of the world's population are disabled. While all human rights treaties apply to persons with disabilities, a specific convention was needed because these people were not able to enjoy the human rights that were granted to them (Quinn \&Degener, 2002; McKay, 2007). Existing human rights instruments were not conducive to taking the specific situation of persons with disabilities into account. In addition to direct and indirect discrimination against people with disabilities in all 
societies, international human rights bodies, such as the United Nations Human Rights Commission (and later the Human Rights Council), and treaty bodies, such as the Human Rights Committee or the Committee on Economic, Social and Cultural Rights, payed little attention to violations of rights of persons with disabilities (Quinn \&Degener 2002).'

Research results and statistics gathered by international organizations and academic researchers speak to the invisibility, the marginalization, and the systematic violations of human rights that persons with disabilities have had to endure (McKay, 2007, p.324-326). According to a study by the World Bank, the education gap between children with disabilities and children without disabilities keeps increasing (Male \& Chata, 2017). A report prepared for UNESCO found that the literacy rate of persons with disabilities is $3 \%$ (Rousso, 2003). The unemployment rate of persons with disabilities can reach $80 \%$ in some countries (WHO, 20I I). Women and girls with disabilities are much more likely to be victims of violence, and particularly sexual violence, than others (Peckham, 2007; Chenoweth, 1999; Brown, 2003). The importance of promoting the rights of persons with disabilities and of giving their situation special attention through a binding treaty is thus undisputable.

What is even more remarkable is that such a specialized treaty that focuses on a minority group could have an important impact on international human rights law more generally. This article explores the influence that the CRPD has had, or may have in the future, on international law both in procedural and in substantive terms ${ }^{2}$.

The first part of the article examines the CRPD's contribution to procedural aspects of international law. First, the CRPD was negotiated inan innovative way, and this article will specifically focus on the participation of civil society in the development of international law. ${ }^{3}$ Second, the CRPD includes new types of provisions on monitoring compliance with the treaty. The participation of civil society led to the adoption of innovative monitoring mechanisms that have been effective since the entry of the convention into force in 2008.

In a second part, the article examines the contribution of the CRPD to international human rights law in substance. It will discuss certain key notions that are developed through the convention, their application and interpretation. First, it focuses particularly on the concept of equality and related notions. The innovations stem both from the text of the convention itself and from the subsequent work of the Committee on the Rights of Persons with Disabilities. Second, this part highlights how

I There is a notable exception: Committee on Economic, Social and Cultural Rights' General Comment no 5 (1995). Yet, this was not sufficient to influence practice (Lawson, 2007, p.577) 2 Sections $2.1,3.2$, and 3.3 of this article are a modified version of a previously published article by the author (Paré, 2009).

3 This article refers to NGOs (non-governmental organisations) to mean civil society in general, as well as disabled peoples organisations in particular. 
the convention has contributed to the fading of the traditional discussion between civil and political rights, and economic, social and cultural rights. Third, the article discusses the link between human rights and development, noting how the CRPD has allowed reframing this link in a very constructive way, after decades of acrimonious debates and empty statements in relation to the right to development.

While the implementation of the CRPD is well under waynow ten years after its entry into force, it is still quite early to evaluate the importance of its contribution to international human rights law generally. This paper concludes that it is important to monitor the way in which the new concepts are applied both in relation to the implementation of the CRPD and other human rights treaties. Moreover, lawyers, activists and policy makers should refer to the new gains identified in this paper when interpreting international human rights law, and when developing new instruments. Otherwise, there is the risk that the gains may go unnoticed, or stay in the realm of disability rights, while they could be referred to as important precedents in international human rights law.

\section{PROCEDURES OF INTERNATIONAL HUMAN RIGHTS LAW}

The CRPD was established through innovative procedures, and the convention establishes new procedures for its monitoring. Thus, the development process of the CRPD has an impact on the making of international human rights law, and the text that is the result of this process provides for new types of procedures when monitoring international human rights law.

\section{I. The development of international human rights law}

It goes without saying that international law is constantly evolving. While states remain the primary subjects of international law, other actors are taking an increasingly important role on the international scene. In the field of international human rights law this trend translates into civil society' growing role in the elaboration, implementation and monitoring of international human rights instruments. This section examines the role of civil society particularly in the development of international law, while its role in monitoring will be discussed as part of the next section.

The United Nations General Assembly decided to start drafting a convention on disability rights at its $56^{\text {th }}$ session in $200 \mathrm{I}$, establishing an Ad Hoc Committee "to consider proposals for a comprehensive and integral international convention to promote and protect the rights and dignity of persons with disabilities" (General Assembly resolution 56/168, 200I). This resolution and subsequent ones invited NGOs to contribute to the work of the Ad Hoc Committee. In addition, NGOs' participation was encouraged and facilitated through modalities established through General Assembly resolutions and decision by the Ad Hoc Committee, which held its first meeting in 2002. Among others, a special accreditation procedure allowed 
NGOs not with a consultative status with the Economic and Social Council to be accredited and therefore to participate in the Ad Hoc Committee's meetings (General Assembly resolution 56/5 10, 2002). Modalities of participation, that were favourable to NGOs, were established by the Ad Hoc Committee, including the possibility to give oral statements, making written presentations, and receiving copies of official documents (General Assembly, A/57/357, 2002). In addition, a voluntary fund for contributions was established to encourage the participation of NGOS from developing countries (General Assembly resolution 57/229, 2002). While some decisions and resolutions specified that the provisions on NGO participation should not be considered as precedents, it is to be expected they will be used informally as precedents by states that are favourable to robust civil society participation in international negotiations. The more often NGOs are included in a meaningul way, the more this becomes common practice, without even needing to refer to specific resolutions adopted in the past.

As such, while NGO involvement was not new at the UN during the drafting of the CRPD, the practice was improved upon previous experiences. The most relevant previous experiences include the drafting of the Declaration on the Rights of Indigenous Peoples by the Working Group on Indigenous Populations, during which the participation of civil society was encouraged. This was also done through bending of the rules on accreditation procedures set up by the Economic and Social Council(Sanders, 1989 , p.419; Commission on Human Rights resolution 1995/32) and the setting up of a voluntary fund (General Assembly resolution 40/I 3 I , 1985). The main originality of the Ad Hoc Committee's practice was the setting up of a Working Group to prepare a draft of the convention on the rights of persons with disabilities (General Assembly, A/58/I I 8, 2003, para. 15). Unlike the Working Group on Indigenous Populations, composed of experts, the Ad Hoc Committee's working group was composed of 27 state representatives, a representative from national human rights institutions, and $12 \mathrm{NGO}$ representatives, selected by NGOs on the basis of disability and regional representation. All members worked on an equal footing, and had to consider, equally, contributions for texts submitted by states, NGOs, and other entities. This was the first time ever that NGOs were treated equally with states in a context of international law making. After the work of the Working Group was completed, the negotiations at the Ad Hoc Committee's meetings were based on a text that was heavily influenced by NGOs.

In addition to NGOs' formal participation in the Working Group, the Ad Hoc Committee adapted its procedures to facilitate NGO participation and contributions, and it is said that the Ad Hoc Committee meetings were the most inclusive in the history of the UN (Kanter, 2007, p.294). While there was no uniform view on the extent to which NGOs should participate in proceedings, the Ad Hoc Committee reached an agreement initially on modalities of NGO participation (General Assembly A/57/357, 2002). However, subsequent practice was based on the flexibility demonstrated by the Chair of the Committee. The Chair allowed NGOs to participate in informal 
meetings, contrary to UN practice, and suspended the "informals" to allow NGOs to make oral contributions, thus getting around previously established rules. Even at the very end of the negotiation process, NGOs could attend meetings called "informal informals" as observers, and Ad Hoc Committee members would sometimes call on the NGOs present in the room to give clarifications or viewpoints as specialists. ${ }^{4}$ This sustained participation, and states' positive attitude towards it, was facilitated by the fact that the NGOs were organised as an International Disability Caucus (IDC). ${ }^{5}$ While the IDC was already established at the first meeting of the Ad Hoc Committee, its work became increasingly effective and sophisticated, as NGOs gained in negotiation and legal argumentation skills. NGOs were able to make the most of the climate of dialogue to create and strengthen an alliance and develop common positions. This is a notable feat considering the diversity of NGOs representing different disabilities. ${ }^{6}$

In a final analysis, NGO participation went far beyond the traditional lobbying that civil society members usually resort to in international negotiations. This is even more significant considering that the Ad Hoc Committee was a subsidiary organ of the General Assembly, where NGO participation is much more limited than it is in the Economic and Social Council. Thanks to states' openness to NGO participation and NGOs' own organization into an effective interlocutor, the mantra "Nothing About us Without Us" got hammered in the text of the CRPD itself:

In the development and implementation of legislation and policies to implement the present Convention, and in other decision-making processes concerning issues relating to persons with disabilities, States Parties shall closely consult with and actively involve persons with disabilities, including children with disabilities, through their representative organizations. (art. 4.3)

\subsection{Implementation and monitoring}

Monitoring is also an area where NGOs were able to make a difference during the development of the CRPD. In addition to the place of disabled peoples organizations

4 There are no written reports of these informal meetings. The comment is based on the author's experience in these meetings, as well as some accounts by others present. See for instance Maria V. Reina "How the International Disability Caucus worked during negotiations for a UN Human Rights Convention on Disability", 2008, Global Action on Aging: " http:// globalag.igc.org/agingwatch/events/CSD/2008/maria.htm

5 The development of the rights of indigenous peoples provides also a precedent here, as Indigenous Peoples organised as an Indigenous Peoples Caucus during negotiations (Gilbert, 2007, p.214).

6 The IDC had over 70 members towards the end of the negotiations. 
in implementing the convention, their active participation in the negotiation of the treaty led also to their inclusion in monitoring the convention: "Civil society, in particular persons with disabilities and their representative organizations, shall be involved and participate fully in the monitoring process" (art. 33.3). As well, states are expected to encourage the formation of disabled people's organizations, and to encourage the participation of persons with disabilities in these and in other NGOs (art. 29 (b)).In addition to the participation of NGOs in monitoring the convention, the provision on monitoring at the national level also encourages the establishment of a focal point within government, and a coordination mechanism to facilitate action in different levels and actions of government (art. 33.1). Outside governments' implementation and monitoring role, states are to "maintain, strengthen, designate or establish" one or more independent mechanisms to "to promote, protect and monitor implementation" of the convention (art. 33.2). The CRPD thus goes much further than other international human rights treaties in prescribing measures that states should take to ensure implementation and adequate monitoring mechanisms. Not only is a specific government body to be involved, but many bodies must contribute through a coordination mechanism. In addition,independent institutions guided by the Paris Principleson National Human Rights Institutions (Committee on the Rights of Persons with Disabilities, 2016, p.33), and civil society, particularly disabled people's organisations, should be involved in implementation and monitoring.

For monitoring compliance with the CRPD at the international level, the negotiators, after long discussions against the backdrop of UN treaty body reform debates (Stein \& Lord, 20 I0, p.692) included a similar system to all major human rights treaties, thus firmly anchoring the CRPD within the group of core international human rights treaties. Article 34 of the CRPD establishes a Committee on the Rights of Persons with Disabilities that carries out similar functions to other treatybased bodies within the UN human rights system. The Committee examines states' periodic reports on the implementation of the CRPD, and, in accordance with the Optional Protocol to the CRPD, it can receive and consider communications on violations of the convention, as well as conduct inquiries with the consent of the state party concerned. While the treaty body-based monitoring system is not very innovative as such, ${ }^{7}$ what was new, was the adoption of the Optional Protocol on a communications and inquiry procedure at the same time as the convention itself. For other human rights conventions, communications procedures have been objects of separate negotiations leading to the adoption of optional protocols years later.

In addition to the traditional international monitoring mechanism, another interesting monitoring provision was added to the CRPD, namely a Conference of

7 However, Stein \&Lord (2010) note some innovations, including the possibility of collective complaints (p.697). 
States Parties (art. 40). The CRPD provides that stats parties shall meet regularly to consider matters regarding the implementation of the convention, exchanging best practices and discussing challenges. This is the first time that such a mechanism is instituted in relation to the monitoring of a human rights convention. ${ }^{8}$ The conference, which is well attended by states and civil society actors, has addressed many themes, including statistics, discrimination, urban development, humanitarian action, poverty elimination, information and technology, employment, independent living, political participation, etc. It would be possible to envision such a mechanism for other human rights treaties as well. This could encourage a more cooperative approach, instead of, or in addition to, a rather defensive one that relies on traditional monitoring mechanisms and complaints procedures. It would also encourage ongoing dialogue between different stakeholders (on the potential of conferences of States parties, see Stein \& Lord 20 I0).

\section{THE SUBSTANCE OF INTERNATIONAL HUMAN RIGHTS LAW}

In addition to procedural innovations, the CRPD offers new ways of looking at the substance of international human rights law. The areas of interest to human rights in the CRPD are many, including the right to education, legal capacity and the rights to liberty and security. The convention has helped to bring to light aspects of these rights that were overlooked before. In the interest of space, this article will concentrate only on three issues of substance that are more of an overarching or general nature: the concept of equality, economic, social and cultural rights in relation to civil and political rights, as well as the links between human rights and development.

\section{I. The concept of equality}

While equality is a right in itself, it is also an overarching principle that applies to all human rights. It is intimately related to non-discrimination. The CRPD addresses and defines both equality and non-discrimination. First of all, it sanctions equality of opportunity as one of its principles (art. 3), thus ending debates over whether equality of opportunity or equality of outcome should apply. Equality of opportunity is grounded in the dignity of the person, and another one of the convention's principles is respect for inherent dignity and individual autonomy. This approach is important for persons with disabilities, as equality of results to could lead to paternalistic measures. Most of the other general principles listed in article 3 are also founded on the principle of equality: non-discrimination, full participation and inclusion in society, respect for

8 A conference of States parties exists mainly for weapons treaties, like the Convention on the Prohibition of the Development, Production, Stockpiling and Use of Chemical Weapons and on their Destruction, the Biological and Toxin Weapons Convention, and the Convention on Certain Conventional Weapons. 
difference and acceptance of persons with disabilities as part of human diversity, equality between men and women, and accessibility. Generally speaking, it is clear that the CRPD is grounded in the principle of non-discrimination. It is not a traditional non-discrimination treaty, such as the International Convention on the Elimination of All Forms of Racial Discrimination (ICERD), as it takes the concept of equality further, and promotes substantive equality as opposed to formal equality. Ittakes concepts, like full participation and equal opportunities,formerly included in non-binding documents, such as the 1982 World Program of Action concerning Disabled Persons and the 1993 Standard Rules on the Equalization of Opportunities for Persons with Disabilities, thus allowing them to be legally protected in a human rights treaty.

In a very practical way, the CRPD adopted the notion of reasonable accommodations, which has existed in some national contexts, but had not previously been included in international human rights law. Reasonable accommodations are "modification and adjustments not imposing a disproportionate or undue burden, where needed in a particular case, to ensure to persons with disabilities the enjoyment or exercise on an equal basis with others of all human rights and fundamental freedoms" (art. 2).Significantly, the CRPD recognizes the denial of reasonable accommodations as a form of discrimination (art. 2), and this enlarges the concept of non-discrimination in international human rights law. The Convention also asks states to ensure that reasonable accommodation is provided in order to promote equality (art. 5.3).

Less explicitly, the CRPD contributes to the notion of intersectionality, which has been introduced in feminist scholarship(Crenshaw 1991), and adapted to international human rights (de Beco 20 17; Truscan\&Bourke-Martignoni 20 I6). In human rights law, intersectionality means that people are sometimes discriminated against on multiple grounds. Although focus was initially on being a woman from a racial minority, the concept has been widened to include other grounds of discrimination. Discrimination on these grounds are interconnected, and cannot be examined separately. Therefore, disabled women experience discrimination based on disability differently from disabled men. The CRPD gives special attention to women with disabilities; it recognizes equality between men and women among its general principles and includes a separate article on women with disabilities, identifying women and girls with disabilities as subjects to multiple discrimination (art. 6). One can imagine the addition of other layers of identity that come and change the experience of discrimination, for example social origin, race, belonging to an indigenous group, age etc.In fact, the CRPD asks states also to combat stereotypes, "including those based on sex and age" in article 8.I b). The convention clearly contributes to the understanding that discrimination is not one-dimensional and requires an increased attention, considering the situation and characteristics of each person (Degener, 2016).

In light of this approach, the CRPD provides for very concrete measures to be taken to promote equality and combat discrimination. Among the general obligations identified in article 5 of the convention, are the following, among others: 
(f) To undertake or promote research and development of universally designed goods, services, equipment and facilities, as defined in article 2 of the present Convention, which should require the minimum possible adaptation and the least cost to meet the specific needs of a person with disabilities, to promote their availability and use, and to promote universal design in the development of standards and guidelines;

(g) To undertake or promote research and development of, and to promote the availability and use of new technologies, including information and communications technologies, mobility aids, devices and assistive technologies, suitable for persons with disabilities, giving priority to technologies at an affordable cost;

(h) To provide accessible information to persons with disabilities about mobility aids, devices and assistive technologies, including new technologies, as well as other forms of assistance, support services and facilities;

(i) To promote the training of professionals and staff working with persons with disabilities in the rights recognized in this Convention so as to better provide the assistance and services guaranteed by those rights.

These obligations, which are directly related to the implementation of the principles of equality and non-discrimination, go far beyond the obligations that are included in other human rights treaties, which ask states to take legislative and other appropriate measures to ensure implementation. ${ }^{9}$ Furthermore, aside from article 5 , the CRPD includes specific provisions on measures that are necessary to effectively apply the principles of equality and non-discrimination. These articles don't include rights as such, but measures and principles that are necessary for the implementation of the convention. Article 8 on awareness-raising, and article 9 on accessibility have specifically that function. For example, measures to promote awareness of the capabilities of persons with disabilities include (art. 8.2):

(a) Initiating and maintaining effective public awareness campaigns [...]

(b) Fostering at all levels of the education system, including in all children from an early age, an attitude of respect for the rights of persons with disabilities;

(c) Encouraging all organs of the media to portray persons with disabilities in a manner consistent with the purpose of the present Convention;

(d) Promoting awareness-training programmes regarding persons with disabilities and the rights of persons with disabilities.

Article 8 thus addresses attitudinal barriers that are obstacles to the equality of persons with disabilities. Article 9 on accessibility addresses physical and communication barriers. This article gives an even more compelling picture of the complexity of actions that are designed to foster equality and to combat discrimination. It asks states

9 See for ex. ICERD, art. 2; Convention on the elimination of all forms of discrimination against women (CEDAW), art. 2, or Convention on the Rights of the Child (CRC), art. 4. 
to ensure that persons with disabilities have access, on an equal basis with others, "to the physical environment, to transportation, to information and communications, including information and communications technologies and systems, and to other facilities and services open or provided to the public, both in urban and in rural areas" (art. 9. I). Among measures that states must take include the following (art. 9.2):

(c) Provide training for stakeholders on accessibility issues facing persons with disabilities;

(d) Provide in buildings and other facilities open to the public signage in Braille and in easy to read and understand forms;

(e) Provide forms of live assistance and intermediaries, including guides, readers and professional sign language interpreters, to facilitate accessibility to buildings and other facilities open to the public;

(g) Promote access for persons with disabilities to new information and communications technologies and systems, including the Internet; [...]

These provisions help us understand that non-discrimination is not a right that can simply be implemented through negative measures, i.e. refraining from discriminatory actions; the latter is the traditional approach to non-discrimination that can be gleaned from the ICERD, for example. This observation brings us to the next point, which deals with the blurring of distinctions between different categories of rights.

\subsection{Economic, social and cultural rights}

The 1993 World conference on human rights held in Vienna had attempted to put an end to polarized discourses on human rights - a Cold War legacy - by declaring the interdependence and indivisibility of human rights (United Nations, 1993). Since then, several attempts had been made by $\cup N$ human rights bodies to bring about recognition of the overly simplistic and incorrect distinctions that have been made between civil and political rights, on the one hand, and economic, social and cultural rights, on the other (see for ex. Human Rights Committee, 1994). According to traditional theories, civil and political rights only entail negative obligations, meaning that the state should refrain from infringing on people's fundamental rights and freedoms, such as the right to privacy, or the right to freedom of expression. As to economic, social and cultural rights, they are recognized as involving positive obligations, meaning that the state must take positive measuresto implement them (Eide, 1995; Van Hoof, 1984). These measures come generally with financial implications, such as ensuring that the state can offer education or health care services.Authors and international bodies have demonstrated that these distinctions are not correct, because all rights entail both positive and negative obligations (Eide\& Rosas, 1995; Shelton \& Gould,20 I3). For example, the right to be free from torture implies positive measures including the training of personnel, surveillance of interrogation methods and of treatment of detainees, inquiry into suspected violations of the right, as well as reparation in case of violation (Paré, 2016, p. I58). Thus the preference is now to refer to obligations to 
respect, protect and provide, instead of negative and positive obligations (Paré, 20 I6, p.72) Such interpretation has also been developed in legal doctrine as well as through the work of international human rights bodies. However, states have continued to be attached to the traditional distinctions, and thus, the CRPD offered an opportunity to include in a binding instruments the result of years of legal development in the field of human rights.

The CRPD is not the first human rights treaty that includes different categories of rights. ${ }^{10}$ However, it is the first treaty that mixes the order of rights. In other treatiesthat address different types of rights, civil and political rights are usually included first, followed by economic, social and cultural rights. During the negotiations of the CRPD, this fact was discussed, and it was decided, for instance, to place participation in political life (art. 29) between adequate standard of living (art. 28) and participation in cultural life (art. 30), specifically to make a point about theabsence of hierarchy between the two categories of rights (Paré, 2009, p.5 I4). Moreover, as the Chair of the Ad Hoc Committee noted, individual articles in the CRPD actually contain both types of rights, which would have made a separation difficult (McKay, 2007, p.330).

The CRPD does not completely put an end to the distinction between civil and political rights, and economic, social and cultural rights, but it makes an important effort to fade the differences. Article 4 on general obligations takes a similar formulation to that included in existing treaties," ' but with an important addition:

With regard to economic, social and cultural rights, each State Party undertakes to take measures to the maximum of its available resources and, where needed, within the framework of international cooperation, with a view to achieving progressively the full realization of these rights, without prejudice to those obligations contained in the present Convention that are immediately applicable according to international law. (art. 4.2, emphasis added)

There is thus the recognition that economic, social and cultural rights require some immediate obligations, as do civil and political rights. This validates the interpretation that has been prevalent among human rights treaty bodies and UN special procedures. This new approach is obvious when one reads provisions that pertain to the application of the convention. For example, article 9 on accessibility of the physical environment, transportation, information and communicationsis directly linked to non-discrimination. Yet, as seen earlier, article 9 directs states to take very specific and concrete measures that will necessarily require progressive realization.

10 For example, the CRC includes all types of rights.

"I See the International Covenant on Economic, Social and Cultural Rights (ICESCR) art. 2. I, and CRC art. 4. 
The accessibility of buildings and modes of communication is relevant, for instance, to rights pertaining to court procedures, or to the right to freedom of expression. Another example is article 8 on awareness-raising that also includes implementation provisions related to non-discrimination. It directs states to "undertake to adopt immediate, effective and appropriate measures" (emphasis added). Finally, a look at the substantive rights demonstrates the inadequacy of the traditional approach to civil and political rights on the one hand and economic, social and cultural rights on the other. For instance, article $2 \mathrm{I}$ on freedom of expression and opinion asks states to "[provide] information [...] in accessible formats and technologies appropriate to different kinds of disabilities in a timely manner and without additional cost" and to "[facilitate] the use of sign languages, Braille, augmentative and alternative communication, and all other accessible means, modes and formats of communication of their choice by persons with disabilities in official interactions". Article 23 on respect for home and the family requests states to "render appropriate assistance to persons with disabilities in the performance of their child-rearing responsibilities" and "undertake to provide early and comprehensive information, services and support to children with disabilities and their families". According to article 29 on participation in political life, states must "[ensure] that voting procedures, facilities and materials are appropriate, accessible and easy to understand and use" and "[facilitate] the use of assistive and new technologies where appropriate". Thus, rights that are traditionally considered as civil and political rights, and subject to immediate implementation, include obligations that resemble those attached to economic, social and cultural rights (see also Kayess\& French, 2008).

Finally, the CRPD has helped to break barriers in relation to the different treatment of economic, social and cultural rights as "second class" human rights by recognizing the justiciability of those rights. Traditionally, only civil and political rights have been considered as justiciable, and only civil and political rights treaties came equipped with a complaints mechanism. As mentioned earlier, the Optional Protocol to the CRPD was adopted at the same time as the convention. It allows for complaint and inquiry procedures for the violations of rights guaranteed by the CRPD. This is significant, because it is the first treaty allowing for individual communications concerning the violation of economic, social and cultural rights. Until the adoption of the optional protocol, such rights were not formallyconsidered as justiciable, because the obligations stemming from those rights were viewed as vague, leaving states such a margin of action that violations could not be properly identified. The work of authors and international organizations on the identification of violations of economic social and cultural rights certainly influenced the CRPD drafters (forex.Leckie 1998; Chapman, 1996; Türk, 1992; Maastricht Guidelines on Violations of Economic, Social and Cultural Rights, 1997).

The negotiations of the CRPD allowed the inclusion in a binding treaty of developments in international law that authors and expert members of UN human 
rights bodies had already initiated. The CRPD negotiators were not ready to entirely eliminate the distinction between the two categories of rights, but given its new take on state obligations and justiciability of rights, the CRPD has made great strides in the recognition of economic, social and cultural rights as rights that are on a par with civil and political rights. It has also allowed seeing civil and political rights under a new light, oriented toward practical application and measures that encourage development.

\subsection{Redefining links between human rights and development}

Until the second half of the 1990s, the link between human rights and development was mostly restricted to the definition of the right to development as a human and peoples' right. The United Nations General Assembly adopted the Declaration on the Right to Development in 1986, but this declaration remained controversial and was never effectively acted upon, despite repeated statements for the recognition ofthis right, such as with the Vienna Declaration and Programme of Action. As the right was drafted in vague terms, authors gave it different definitions without, however, much detail (ex. Alston, 1988, p.20; Bedjaoui, 1991, p. |47- |47।; Sengupta, 2002, p.837889; Paul, 1992, p.235-265).Another link between human rights and development could be made with the reference in treaties including economic, social and cultural rights - and specifically the 1977 International Covenant on Economic, Social and Cultural Rights (ICESCR) and the 1989 Convention on the Rights of the Child (CRC) - to international cooperation for the progressive realization of such rights. The work of the United Nations and other organizations in the areas of human rights and development otherwise stayed separate. In the second half of the 1990s, a human rights-based approach was developed among development and humanitarian agencies, and the UN went through an exercise of mainstreaming human rights into other areas of action of the organization (United Nations Development Group, 2003; Hamm, 2001; Yeshanew, 2014). In 1998, a working group on the right to development was set up to monitor the implementation of the right to development (Commission on Human Rights resolution 1998/72). In 2016, the mandate of a special rapporteur on the right to development was instituted (Human Rights Council resolution resolution $33 / 14$ ) in the perspective of promoting and mainstreaming the right to development.Different attempts have thus been made to recognize development as a human right and to harmonize work in the areas of development and human rights.

The CRPD's approach to development is different from previous efforts. First, it must be mentioned that the CRPD was developed as a hybrid treaty. General Assembly resolution 56/168 established the Ad Hoc Committee charged of drafting a "comprehensive and integral international convention to promote and protect the rights and dignity of persons with disabilities, based on the holistic approach in the work done in the fields of social development, human rights and non-discrimination" (emphasis added). This followed previous work on the social model of disability, the 
recognition of disability as a cause and a consequence of poverty, and the role of social development in the advancement of the situation of persons with disabilities. These links became evident during the International Decade of Disabled Persons (1983-1992), and were inserted in its outcome document: The World Program of Action concerning Disabled Persons. Thus, from the beginning, the CRPD was presented as an atypical treaty, as it was one of the core UN human rights treaties, but inspired by development-related considerations. Disability became a very concrete link between human rights and development, and discussions continued to refer to development throughout negotiations, making the convention particularly interesting for developing countries (Kayess\& French, 2008, p. 17). The result of the place given to development in the negotiations is the acknowledgement of the role of development in the implementation of disability rights, and the recognition of persons with disabilities as agents of social development. The CRPD preamble sets the tone by emphasizing the "importance of mainstreaming disability issues as an integral part of relevant strategies of sustainable development" (g), by recognizing "the importance of international cooperation for improving the living conditions of persons with disabilities in every country, particularly in developing countries" (I), and by stating that "full participation by persons with disabilities will result in their enhanced sense of belonging and in significant advances in the human, social and economic development of society and the eradication of poverty" $(\mathrm{m})$. Within the body of the treaty, article 32 addresses international cooperation, identifying measures that states should take providing, inter alia, technical and economic assistance, and ensuringthat international development programmes are inclusive and accessible to persons with disabilities. The latter is an important point, as it clearly tackles development as a human rights issue, linking it to the principle of non-discrimination. If persons with disabilities are included in development efforts, then they can fight poverty as beneficiaries of development programmes and actors in such programmes, on an equal basis with others. Yet, the second paragraph of article 32 is testimony to the controversies that continue to characterize international cooperation and the idea of the right to development: "The provisions of this article are without prejudice to the obligations of each State Party to fulfil its obligations under the present Convention". All states parties must thus implement the treaty irrespective of the availability and extent of international cooperation.

Despite explicit references to development in the convention, I would argue that the main contribution of the CRPD to creating strong links between development and human rights is through its practical approach to human rights and to nondiscrimination more specifically. The CRPD has gone beyond any other human rights convention in identifying concrete measures that states must take to ensure that persons with disabilities can exercise their rights. Its practical approach makes it possible to surpass political controversies about the nature and extent of the right to development. Such an approach is usually more common in development 
policies than in human rights treaties. This is clear, for instance, when comparing the Standard Rules on the Equalization of Opportunities with the ICESCR, or the Plan of Action adopted at the World Summit for Children and the CRC. As already seen earlier in this article the CRPD includes many provisions that do not declare rights as such; rather, they include specific implementation measures that apply to the whole convention. These provisions include those on accessibility and awareness-raising, as well as statistics and data collection, personal mobility and independent living, among others. For instance, article 19 on independent living provides that persons with disabilities must "have access to a range of in-home, residential and other community support services, including personal assistance necessary to support living and inclusion in the community", while article 20 on personal mobility asks states to facilitate "access by persons with disabilities to quality mobility aids, devices, assistive technologies and forms of live assistance and intermediaries", to provide "training in mobility skills to persons with disabilities and to specialist staff working with persons with disabilities", and to encourage "entities that produce mobility aids, devices and assistive technologies to take into account all aspects of mobility for persons with disabilities". Even many of the traditional human rights articles included in the CRPD specify very concrete measures that states must take to ensure enjoyment of rights by persons with disabilities. For instance, as noted earlier, articles 21 on the freedom of expression and article 29 on participation in political life do not stop at the recognition of the specified right, but include concrete measures for states to take. Equally, article 13 on access to justice provides that states should "promote appropriate training for those working in the field of administration of justice, including police and prison staff" in order to "help to ensure effective access to justice for persons with disabilities". Even articles on the right to health and the right to education, which are already quite detailed in other conventions like the CRC and the ICESCR, go well beyond the level of description in previous treaties. For example, with regards to the right to education, "[e]ffective individualized support measures are provided in environments that maximize academic and social development, consistent with the goal of full inclusion" (CRPD art. 24.2(e)). Training of education professionals "shall incorporate disability awareness and the use of appropriate augmentative and alternative modes, means and formats of communication, educational techniques and materials to support persons with disabilities" (art. 24.4). What this means with regards to development is that if persons with disabilities can effectively exercise their rights- whichshould be ensured by such concrete measures, they are less likely to find themselves in situations of poverty at the margins of development; quite the opposite, they are then more likely to contribute to their society's development.

\section{ASSESSMENT AND WAY FORWARD}

The aim of this paper was to argue that the CRPD has had an important impact on international human rights law through its negotiation process and its inclusion of 
new concepts in international law, as well as the development of new approaches to existing concepts. For instance, the negotiation process gave an unprecedented role to non-governmental actors, which in turn influenced the contents of the convention (McKay, 2007). The convention allows new approaches to the right to non-discrimination and equality, and to the status of different categories of rights in international human rights law. Furthermore, it develops more concrete links between development and human rights than in previous efforts.

After ten years of implementation of the CRPD, it is a good time to take stock of these developments and assess their actual and possible impact on international human rights law. While it is not possible to really determine the influence of a specific convention on the development of law in other areas, it ispossible to suggest that some positive developments may be due to it (see also Degener, 2017). First of all, there has clearly been an accrued and more sustained interest in the situation of persons with disabilities and their rights since the development of the CRPD. While research showed that previously persons with disabilities were not taken into consideration in the implementation and monitoring of international human rights law (Quinn \&Degener, 2002), there has been recently a greater awareness of issues pertaining to persons with disabilities and violations of their rights. This can be seen in the work of human rights bodies, such as the CEDAW, ICESCR, CAT, Human Rights Committee, and other treaty-based bodies. ${ }^{2}$ Moreover, the Human Rights Council has been holding annual discussions on the rights of persons with disabilities since the adoption of the CRPD (Human Rights Council resolution 7/9, 2008). Rights of persons with disabilities are thus recognized outside disability rights, within mainstream human rights.

Second, the adoption, in 2007, of the Optional Protocol to the CRPD establishing a communications procedure was followed by the adoption of similar optional protocols to the ICESCR in 2008, and the CRC in 2011. While there had been discussions on such a treaty for the ICESCR for almost three decades, the adoption of the CRPD Optional Protocol, at the same time as the CRPD itself, most likely helped to speed up negotiations on the ICESCR Optional Protocol, as it was finally adopted in 2008. One could of course mention the Optional Protocol to the CEDAW in I999, but CEDAW is considered as a more traditional non-discrimination convention, while the CRPD is more than a non-discrimination treaty, as this article has demonstrated. Its articles on economic, social and cultural rights are comprehensive, detailing state

12 For instance in case law: ICERD Committee, Opinion adopted concerning communication No. 53/2013, Pjetri v. Swizerland, 2017; CEDAW Committee, Views adopted on communication No. 34/20 I I, R. P. B. v. the Philippines, 20 I4; CEDAW Committee, Views adopted onCommunication No. 3I/20 I I, S.V.P. v. Bulgaria, 2012; Human Rights Committee, Views adopted on Communication No. 200I/20 I O. Q. v. Denmark, 20 15;Human Rights Committee, Views adopted on Communication No. 209I/20I I, A.H.G. and M.R. v. Canada, 2015. 
obligations in relation to these rights. Moreover, article 4 on general measures of implementation recognizes the particular nature of economic, social and cultural rights that are included in the convention.

Third, it is important to note that the fact that development and human rights go hand in hand has become even clearer since the adoption of the CRPD. Suffice to note the adoption of the UN Sustainable Development Goals (SDGs) in 2015 that integrate a robust human rights approach. The SDGs substantially improve on the previously adopted Millennium Development Goals (MDGs), which are not framed in terms of human rights, except for the goal of gender equality. Moreover, contrary to the MDGs, persons with disabilities are specifically included in the SDGs under Goal I: ending poverty; Goal 4: inclusive and equitable quality education; Goal 8: full and productive employment and decent work for all; Goal 10: reducing inequality; Goal I I: making cities inclusive, safe and sustainable; and Goal 17: strengthening the means of implementation and revitalize the global partnership for sustainable development.

Finally, it is important to note the work of the Committee on the Rights of Persons with Disabilities, which is continuing the important work started during the development of the CRPD. The CRPD Committee, through its case law and General Comments, has been able to clarify and further develop concepts that presented some degree of novelty in the convention. For example, the Committee has adopted general comments on accessibility, independent living, and inclusive education, which are all concepts that did not exist in UN human rights treaties before. The Committee has also further developed well-known notions in human rights law. While equality and non-discrimination clearly present new facets in the convention, the Committee on the Rights of Persons with Disabilities (2018 a) adopted General Comment in 2018 helping to further theorize these notions. The General Comment clarifies that disability is one component among other aspects of a person's identity, and introduces the concept of intersectionality. The comment discusses different types of equality, such as equality of opportunity and equality of outcome, and introduces a new concept: inclusive equality. The General Comment addresses also different forms of discrimination, including direct discrimination, indirect discrimination, denial of reasonable accommodation, harassment, and intersectional discrimination, which goes together with the notion of intersectionality discussed throughout the comment. Given how UN treaty bodies and thematic special procedures build on the work of one another and refer to each other's reports, it is quite likely that this kind of theorizing by the CRPD Committee will have an important influence on the development and interpretation of international human rights law more generally. ${ }^{13}$

13 Degener (2017, p. 156) notes this in relation to the influence of the Committee on the Rights of Persons with Disabilities' case law on the practice of other international bodies. 
Finally, it is important to mention the Committee on the Rights of Persons with Disabilities' (20 I 8 b) General Comment on participation of persons with disabilities in the implementation and monitoring of the convention. This comment develops the notion of representative organisations and consultations: how organisations should be consulted, and how representative organizations should be defined. Addressing modes of consultation and characteristics of representative organizations can be especially interesting considering the development of the principle of participation in international law, applicable to different groups, including especially indigenous peoples whose rights are not yet restrained in a binding treaty.

\section{CONCLUSION}

The CRPD has been a trailblazer in many different ways within the fields of international human rights law and social development. It is difficult to fully assess the impact it has had since its development and adoption, but the potential is real. Furthermore, the CRPD's potential for influence has continued to grow since the adoption of the convention, as exemplified by the continuous work of the Committee on the Rights of Persons with Disabilities. The international community should capitalize on the new approaches introduced by the convention and its development, in order to promote the building of a society for all.Lawyers, human rights activists, policy makers and other actors within and outside the United Nations have an important role in referring to gains made in the field of disability rights when interpreting and developing international human rights law. To quote Gerard Quinn (2009, p.5 I), the convention "articulates a theory of justice that every citizen can subscribe to and in which every citizen has a stake. It is not a case of special rights for a particular group; it is about equal rights for all."

\section{REFERENCES}

ALSTON, Paul. Making Space for New Human Rights: The Case of the Right to Development. (1988)I Harvard Human Rights Yearbook3.

BEDJAOUI, Mohammed.Le droit au development. In BEDJAOUI, Mohammed (ed). Droit international: Bilan et perspectives. Paris: Pedone, |991.

BROWN, Hilary. Safeguarding adults and children with disabilities against abuse. Strasbourg: Council of Europe, 2003.

CHAPMAN, Audrey. A Violations Approach for Monitoring the International Covenant on Economic, Social and Cultural Rights. (1996) I8: I Human Rights Quarterly 23.

CHENOWETH, Leslie. Sexual Abuse of People with Disabilities. In JONES M \&BASSER MARKS L.A. (ed.), Disability, Divers-ability and Legal Change. Dodrecht: Martinus Nijhoff pub., 1999. 
THE CONVENTION ON THE RIGHTS OF PERSONS WITH DISABILITIES: ITS CONTRIBUTION TO THE DEVELOPMENT OF INTERNATIONAL HUMAN RIGHTS LAW

COMMITTEE ON ECONOMIC, SOCIAL AND CULTURAL RIGHTS, General Comment no.5: Persons with Disabilities, UN Doc. E/I995/22.

COMMITTEE ON THE RIGHTS OF PERSONS WITH DISABILITIES, Rules of Procedure, Annex: Guidelines on independent monitoring frameworks and their participation in the work of the Committee on the Rights of Persons with Disabilities UN Doc. CRPD/C/I/Rev. I, 2016.

COMMITTEE ON THE RIGHTS OF PERSONS WITH DISABILITIES (2018 a) General comment No. 6 (20l8) on equality and non-discrimination, UN Doc. CRPD/C/GC/7.

COMMITTEE ON THE RIGHTS OF PERSONS WITH DISABILITIES (2018 b) General comment No. 7 on the participation of persons with disabilities, including children with disabilities, through their representative, organizations, in the implementation and monitoring of the Convention, UN Doc. CRPD/C/GC/7.

CRENSHAW, Kimberlé. Mapping the Margins: Intersectionality, Identity Politics, and Violence Against Womenof Color. ( 99 I) 43:6 Stanford Law Review I24 I

DE BECO, Gauthier. Protecting the Invisible: An Intersectional Approach to International Human Rights Law. (2017) 17:4Human Rights Law Review 633.

DEGENER, Theresia. Disability in a Human Rights Context. (2016) 5 Laws 35.

DEGENER, Theresia. 10 years of Convention on the Rights of Persons with Disabilities. (2017) 35(3) Netherlands Quarterly of Human Rights I 52.

EIDE, Asbjorn. Economic, Social and Cultural Rights as Human Rights. In Asbjorn EIDE et al. (eds), Economic, Social and Cultural Rights. A Textbook. Dodrecht: Martinus Nijhoff, 1995.

EIDE, Asbjorn \& Allan Rosas. Economic, Social and Cultural Rights: A Universal Challenge. In Asbjorn EIDE et al. (eds), Economic, Social and Cultural Rights. A Textbook. Dodrecht: Martinus Nijhoff, 1995.

GILBERT, Jérémie. Indigenous Rights in the Making: The United Nations Declaration on the Rights of Indigenous Peoples. (2007) I 4 International Journal on Minority and Group Rights 207.

HAMM, Brigitte.A Human Rights Approach to Development. (200I) 23:4 Human Rights Quarterly 1005.

HUMAN RIGHTS COMMITTEE. General Comment No. 6: article 6 (Right to Life). UN Doc. HRI/GEN/I/Rev. I, 1994. 
KANTER, Arlene. The promise and challenge of the United Nations Convention on the Rights of Persons with Disabilities. (2007) 34 Syracuse Journal of International Law and Commerce 287.

KAYESS, Rosemary \& Phillip French. Out of Darkness into Light? Introducing the Convention on the Rights of Persons with Disabilities. (2008) 8 Human Rights Law Review I.

LAWSON, Anna. The United Nations Convention on the Rights of Persons with Disabilities: New Era or False Dawn?. (2007) 34 Syracuse Journal of International Law and Commerce 563.

LECKIE, Scott. Violations of Economic, Social and Cultural Rights. (1998) 20SIM Special.

MALE, Chata\& Quentin WODON. The Price of Exclusion: Disability and Education. Disability Gaps in Educational Attainment and Literacy, Washington DC: The World Bank, 2017.

MCKAY, Don. The United Nations Convention on the Rights of Persons with Disabilities (2007) 34 Syracuse Journal of International Law and Commerce 323.

PARÉ, Mona. Droit international des droits de la personne - systèmes et enjeux. Montreal: LexisNexis, 2016.

PARÉ, Mona. La Convention relative aux droits des personnes handicapées: Quel impact sur le droit international? (2009) 3 Revue générale de droit international public 497.

PECKHAM Nicholas G. The Vulnerability and sexual abuse of people with learning disabilities. (2007) 35:2 British Journal of Learning Disabilities I3I.

PAUL, James. Human Right to Development: its meaning and importance. (1992) 25:2 John Marshall Law Rev 235.

QUINN, Gerard. The United Nations Convention on the Rights of Persons with Disabilities: Toward a New International Politics of Disability. (2009) I 5 Texas Journal on Civil Liberties and Civil Rights 33.

QUINN, Gerard \&DEGENER, Theresia. Human rights and disability: the current use and future potential of United Nations human rights instruments in the Context of Disability. New York \& Geneva: United Nations, 2002.

ROUSSO, Harilyn. Education for All: a gender and disability perspective. Background paper for the Education for All Global Monitoring Report. Paris: UNESCO, 2003. 
THE CONVENTION ON THE RIGHTS OF PERSONS WITH DISABILITIES: ITS CONTRIBUTION TO THE DEVELOPMENT OF INTERNATIONAL HUMAN RIGHTS LAW

SANDERS, Douglas. The UN Working Group on Indigenous Populations. (1989) I I:3 Human Rights Quarterly 406.

SENGUPTA, Arjun. On the Theory and Practice of the Right to Development. (2002) 24:4 Human Rights Quarterly 837.

SHELTON, Dinah \& Ariel GOULD. Positive and Negative Obligations. In Dinah Shelton (ed.).The Oxford Handbook of International Human Rights Law. Oxford: Oxford University Press, 2013.

STEIN, Micheal \& Janet LORD. Convention on the Rights of Persons with Disabilities:Innovations, Lost Opportunities, and Future Potential. (20 I0) 32 Human Rights Quarterly 689.

TRUSCAN, Ivona\& Joanna BOURKE-MARTIGNONI. International Human Rights Law and Intersectional Discrimination. (2016) I6 The Equal Rights Review 103.

TÜRK, Danilo. Special Rapporteur on the realization of economic, social and cultural rights. Final Report. UN Doc. E/CN.4/Sub.2/1992/16.

UNITED NATIONS. Vienna Declaration and Programme of Action, UN Doc. A/ CONF. I 57/23, 1993.

UNITED NATIONS. From exclusion to reality: Realizing the Rights of Persons with Disabilities. Handbook for Parliamentarians. Geneva: United Nations, 2007.

UNITED NATIONS DEVELOPMENT GROUP. The Human Rights Based Approach to Development Cooperation: Towards a Common Understanding Among UN Agencies. 2003.

VAN HOOF, G.J.H. The Legal Nature of Economic, Social and Cultural Rights: A Rebuttal of Some Traditional Views. In Paul ALSTON \& Katarina TOMASEVSKI (eds.). The Right to Food. Dodrecht: Martinus Nijhoff, 1984.

WORLD HEALTH ORGANISATION (WHO).World Report on Disability. Geneva: $\mathrm{WHO}, 201 \mathrm{I}$.

YESHANEW, SisayAlemahu. Mainstreaming Human Rights in Development Programmes and Projects: Experience from the Work of a United Nations Agency. (2014) 32:4 Nordic Journal of Human Rights 372.

Recebido em: 14/04/2019

Aprovado em: 17/05/2019 
